REVIEW

\title{
Neurological channelopathies
}

\author{
T D Graves, M G Hanna
}

Postgrad Med J 2005;81:20-32. doi: 10.1136/pgmj.2004.022012

lon channels are membrane-bound proteins that perform key functions in virtually all human cells. Such channels are critically important for the normal function of the excitable tissues of the nervous system, such as muscle and brain. Until relatively recently it was considered that dysfunction of ion channels in the nervous system would be incompatible with life. However, an increasing number of human diseases associated with dysfunctional ion channels are now recognised. Such neurological channelopathies are frequently genetically determined but may also arise through autoimmune mechanisms. In this article clinical, genetic, immunological, and electrophysiological aspects of this expanding group of neurological disorders are reviewed. Clinical situations in which a neurological channelopathy should enter into the differential diagnosis are highlighted. Some practical guidance on how to investigate and treat this complex group of disorders is also included.

See end of article for authors' affiliations .....................

Correspondence to: Dr Michael G Hanna, Department of Molecular Neuroscience and Centre for Neuromuscular Disease, National Hospital for Neurology and Neurosurgery, Queen Square, London WCIN 3BG, UK; mhanna@ ion.ucl.ac.uk

Submitted 14 March 2004 Accepted 18 May 2004 , autoimmune, and molecular pathor siological features of the neurological channelopathies.

\section{CLASSIFICATION OF ION CHANNELS}

Different classifications of ion channels exist. For the purpose of this review we have classified ion channels into two broad categories depending on their mode of activation-that is, voltage gated neurological channelopathies are subdivided on the basis of channel type. Table 2 is a list of genetic neurological channelopathies according to ion type. Most ion channels have a similar basic structure. All voltage gated ion channels have a large pore forming subunit, which sits within the membrane. The pore forming subunit (also called the $\alpha$-subunit) contains a central aqueous pore through which the relevant ion passes in response to voltage change induced activation, also known as gating. In addition to the main $\alpha$-subunit, it is common for voltage gated ion channels to possess accessory subunits, these subunits may be cytoplasmic or extracellular. Generally, these have an important function in modulating the basic conductance function of the $\alpha$-subunits. The structural topology of all voltage gated ion channels is remarkably conserved through evolution. To date, most genetic neurological channelopathies affecting the peripheral nervous system (PNS) and central nervous system (CNS) are caused by $\alpha$-subunit mutations, resulting in dysfunction of voltage gated ion channels. However, examples of genetic channelopathies due to dysfunction of ligand gated channels are recognised, particularly in the PNS and are emerging in the CNS. To date most autoimmune channelopathies affect the PNS, although CNS examples are likely to increase in the future.

\section{INHERITED CHANNELOPATHIES \\ Muscle channelopathies \\ Myotonic syndromes}

Myotonia is the term given to delayed relaxation of skeletal muscle after voluntary contraction. In most situations myotonia is most marked after initial muscle contraction, and usually abates after repeated muscle activity (the warm-up phenomenon). Electophysiologically, myotonia is a disturbance of the normal excitability of the skeletal muscle membrane. There is an abnormally increased excitability of the membrane such that in response to a depolarising stimulus, for example, a nerve impulse, rather than a single muscle contraction being initiated, multiple contractions occur and this results in the delayed relaxation observed clinically.

From a practical point of view a myotonic disorder should be considered in the differential and ligand gated. Table 1 shows how the genetic
Abbreviations: CMAP, compound muscle action potential; CNS, central nervous system; HyperKPP, hyperkalaemic periodic paralysis; HypoKPP, hypokalaemic periodic paralysis; LEMS, Lambert-Eaton myasthenic syndrome; PCD, paraneoplastic cerebellar degeneration; PNS, peripheral nervous system; SCA6, spinocerebellar ataxia type 6; SCLC, small cell lung carcinoma 


\begin{tabular}{|c|c|c|}
\hline & Muscle & Central nervous system \\
\hline $\begin{array}{l}\text { Voltage gated } \\
\text { channels }\end{array}$ & $\begin{array}{l}\text { Hypokalaemic } \\
\text { periodic paralysis } \\
\text { Hyperkalaemic } \\
\text { periodic paralysis } \\
\text { Andersen's syndrome } \\
\text { Myotonia congenita } \\
\text { Paramyotonia congenita } \\
\text { Malignant hyperthermia }\end{array}$ & $\begin{array}{l}\text { Episodic ataxia type } 1 \\
\text { Episodic ataxia type } 2 \\
\text { Familial hemiplegic migraine } \\
\text { Several inherited epilepsy } \\
\text { syndromes }\end{array}$ \\
\hline $\begin{array}{l}\text { Ligand gated } \\
\text { channels }\end{array}$ & $\begin{array}{l}\text { Congenital } \\
\text { myasthenia gravis }\end{array}$ & $\begin{array}{l}\text { Hyperekplexia } \\
\text { Autosomal dominant } \\
\text { nocturnal frontal lobe } \\
\text { epilepsy }\end{array}$ \\
\hline
\end{tabular}

diagnosis of a patient complaining of muscle stiffness. Myotonic dystrophy is a common and important cause of myotonia but the presence of extramuscular systemic symptoms and signs usually aid the diagnosis. The pure myotonic disorders considered here do not cause multisystem disease. For these disorders, particular attention should be paid to any family history and to the precipitants of the muscle stiffness, for example, temperature and whether the patient's stiffness reduces with exercise-the so called warm-up phenomenon or whether stiffness increases with exercise-so called paradoxical myotonia (see below). Furthermore the presence of muscle hypertrophy should be sought on examination and may be a clue to a chloride channel myotonia.

\section{Myotonia congenita}

See table 3 for clinical features.

\section{Thomsen's disease}

Dr Thomsen initially described this in his own family in 1876. Patients usually present between infancy and adulthood with mild myotonia, which may be constant or intermittent. Marked improvement in myotonia is noted with repeated exercise of a given muscle, the warm-up phenomenon. While $90 \%$ show myotonia on electromyography, only $50 \%$ have percussion myotonia on examination. There is usually normal power at rest, although some have proximal weakness, which can present with functional difficulties such as climbing stairs. Some patients have muscle hypertrophy while others complain of myalgia. Electromyography shows myotonia with a distal predominance, which is present even in early childhood and the warm-up effect can be observed electrophysiologically.

Thomsen's disease is caused by mutations in a muscle voltage gated chloride channel (CLCNI) located on chromosome $7 \mathrm{q} 35 .{ }^{1}$ It is transmitted as an autosomal dominant trait with variable penetrance, although $90 \%$ of affected individuals are symptomatic. This channel exists as a dimer, mutations may interfere with dimerisation by exerting a dominant negative effect on the wild-type subunits. ${ }^{2}$ Since chloride conductance is necessary to stabilise the high resting membrane potential of skeletal muscle, the loss of chloride conductance caused by mutations results in partial depolarisation of the membrane allowing increased excitability and myotonia. ${ }^{3}$

\begin{tabular}{|c|c|c|c|c|}
\hline Channel & Muscle & Gene & CNS & Gene \\
\hline \multirow[t]{3}{*}{ Sodium channel } & $\begin{array}{l}\text { Hypokalaemic periodic } \\
\text { paralysis }\end{array}$ & SCN4A & \multirow[t]{4}{*}{$\begin{array}{l}\text { Generalised epilepsy with } \\
\text { febrile seizures plus } \\
\text { syndrome (GEFS+), } \\
\text { severe myoclonic epilepsy } \\
\text { of infancy }\end{array}$} & \multirow[t]{4}{*}{$\begin{array}{l}\text { SCNIA } \\
\text { SCNIB } \\
\text { SCN2A }\end{array}$} \\
\hline & $\begin{array}{l}\text { Hyperkalaemic periodic } \\
\text { paralysis }\end{array}$ & SCN4A & & \\
\hline & $\begin{array}{l}\text { Paramyotonia congenita } \\
\text { Potassium aggravated } \\
\text { myotonia }\end{array}$ & $\begin{array}{l}\text { SCN4A } \\
\text { SCN4A }\end{array}$ & & \\
\hline Chloride channel & $\begin{array}{l}\text { Myotonia congenita: } \\
\text { Thomsen's, Becker's }\end{array}$ & $\mathrm{CLCN} 1$ & & \\
\hline \multirow[t]{3}{*}{ Calcium channel } & $\begin{array}{l}\text { Hypokalaemic periodic } \\
\text { paralysis }\end{array}$ & CACNAIS & Episodic ataxia type 2 & \multirow[t]{3}{*}{ CACNAIA } \\
\hline & Malignant hyperthermia & $\begin{array}{l}\text { CACNA1S } \\
\text { CACNL2A }\end{array}$ & $\begin{array}{l}\text { Familial hemiplegic } \\
\text { migraine }\end{array}$ & \\
\hline & & & Childhood absence epilepsy & \\
\hline \multirow{3}{*}{ Potassium channel } & Andersen's syndrome & KCNJ2 & \multirow{5}{*}{$\begin{array}{l}\text { Episodic ataxia type } 1 \\
\text { Benign familial } \\
\text { neonatal convulsions }\end{array}$} & \multirow{5}{*}{$\begin{array}{l}\text { KCNA1 } \\
\text { KCNQ2 } \\
\text { KCNQ3 }\end{array}$} \\
\hline & Hypokalaemic periodic & KCNE3 & & \\
\hline & $\begin{array}{l}\text { Hyperkalaemic periodic } \\
\text { paralysis }\end{array}$ & KCNE3 & & \\
\hline \multirow[t]{2}{*}{ Ryanodine receptor } & Malignant hyperthermia & RYR1 & & \\
\hline & Central core disease & RYR1 & & \\
\hline Glycine receptor & & & Hyperekplexia & GLRA1 \\
\hline $\begin{array}{l}\text { Acetylcholine } \\
\text { receptor }\end{array}$ & & & $\begin{array}{l}\text { Autosomal dominant } \\
\text { frontal lobe epilepsy }\end{array}$ & $\begin{array}{l}\text { CHRNB2 } \\
\text { CHRNA4 }\end{array}$ \\
\hline GABA receptor & & & $\begin{array}{l}\text { GEFS+, juvenile } \\
\text { myoclonic epilepsy }\end{array}$ & GABRG2 \\
\hline
\end{tabular}


Table 3 Clinical features of myotonia and paramyotonia congenita

\begin{tabular}{|c|c|c|c|}
\hline & \multirow[b]{2}{*}{ Paramyotonia congenita } & \multicolumn{2}{|l|}{ Myotonia congenita } \\
\hline & & Thomsen's & Becker's \\
\hline Inheritance & Autosomal dominant & Autosomal dominant & Autosomal recessive \\
\hline Age of onset & Neonatal to infancy & Early childhood & First decade \\
\hline Anatomical distribution & Face, tongue, neck, arms & Face, arms $>$ legs & Legs $>$ arms, face \\
\hline Exacerbating factors & Cold, exertion, spontaneous & \multicolumn{2}{|c|}{ Cold, rest, hunger, fatigue, stress } \\
\hline Clinical features & $\begin{array}{l}\text { Cold induced weakness } \\
\text { usually lasts a few } \\
\text { minutes, but occasionally } \\
\text { days some associated } \\
\text { with HyperKPP }\end{array}$ & & $\begin{array}{l}\text { Myotonia generally more } \\
\text { disabling than in Thomsen's } \\
\text { disease. Transient weakness, } \\
\text { some have progressive } \\
\text { weakness }\end{array}$ \\
\hline Muscle hypertrophy & Absent & Present & Present \\
\hline $\begin{array}{l}\text { Cold immersion } \\
\text { electromyography findings }\end{array}$ & $\begin{array}{l}\text { CMAP amplitude } \\
\text { decrement with cooling }\end{array}$ & \multicolumn{2}{|l|}{ No decrement } \\
\hline Treatment & Mexilitine, ${ }^{9}$ acetazolamide & \multicolumn{2}{|l|}{ Mexilitine ${ }^{4}$ phenytoin $^{73}$} \\
\hline lon channel gene & Sodium channel $(\mathrm{SCN} 4 \mathrm{~A})^{7}$ & \multicolumn{2}{|c|}{ Chloride channel (CLCN1)' } \\
\hline
\end{tabular}

\section{Becker's disease}

The Becker form of myotonia congenita is more severe than Thomsen's disease with an earlier age of onset. As in Thomsen's disease there is myotonia with the warm-up phenomenon but patients also have significant muscle hypertrophy, especially in the gluteal muscles. There may also be mild distal muscle weakness. Strength is normal initially but there may be rapid decrease in power with short amounts of exercise, which returns to normal after further muscle contraction. Such transient weakness in Becker patients is more likely to happen after a period of rest. For example after sitting for a while a patient may experience a transient lower limb weakness on standing. The electromyogram shows frequent myotonic discharges and the warm-up effect can be demonstrated. In contrast to Thomsen's disease the motor units are frequently mildly myopathic. Becker's disease is also due to mutations in the muscle chloride channel (CLCN1), ${ }^{1}$ hence the two forms of myotonia congenita are allelic. However, Becker's disease shows autosomal recessive inheritance. There is a male predominance, suggesting reduced penetrance or a milder clinical phenotype in females. Mutations have been found throughout the gene, with missense and nonsense mutations and deletions identified. Most patients are compound heterozygotes. Expression studies have indicated that the majority of mutations result in a loss of function of the chloride channel monomer. ${ }^{2}$

\section{Practical management}

Many patients with myotonia congenita do not require medication, but in our experience those that do usually respond well to mexiletine. Other antimyotonic agents can be considered and include phenytoin, but these are less effective. ${ }^{4}$ Mexilitene causes use-dependent blockade of sodium channels and stops the production of repetitive runs of action potentials and hence reduces muscle stiffness. However, it can lead to arrhythmias, including torsades de pointes and as it is unlicensed in the UK for myotonia and approval should therefore be sought from local use of medicines committees. We suggest that it is only prescribed by neurologists with experience of its use in this context. Mexilitine treatment requires close monitoring with electrocardiography. Ultimately a specific chloride channel opening agent would be the ideal therapy for such patients but such a drug has not been developed to date. Accurate genetic counselling is important, especially with regards to risks to offspring and this relies on the availability of a precise DNA based diagnosis.

\section{Potassium aggravated myotonias}

This is an umbrella term for several conditions due to mutations in the skeletal muscle voltage gated sodium channel, SCN4A (described in detail below). Clinically patients exhibit pure myotonia of variable severity, which can be particularly sensitive to potassium ingestion with no associated weakness. Clinically, distinction from myotonia congenita, described above, may be difficult. Various terms have been used to describe these disorders, which are summarised below.

\section{Myotonia fluctuans}

This is characterised by mild myotonia that varies in severity from day to day with no weakness or cold sensitivity. Stiffness typically develops during rest after a period of exercise and lasts for approximately one hour. It is exacerbated by potassium and depolarising agents (for example, suxamethonium) and may interfere with respiration. The electromyogram shows myotonia which increases after exercise. $^{5}$

\section{Myotonia permanens}

In this condition patients experience severe continuous myotonia, which may interfere with respiration. There is often marked muscle hypertrophy, especially in the neck and shoulders.

\section{Acetazolamide responsive myotonia congenita}

This is characterised by muscle hypertrophy, myotonia and myalgia, is aggravated by potassium loading and improved by acetazolamide. $^{6}$

\section{Paramyotonia congenita}

"Paradoxical" myotonia is stiffness (myotonia) that appears during exercise and worsens with continued activity. Electromyography at rest often shows some myotonia, although it is often less prominent than in the other myotonias described above. Low temperature often precipitates symptoms in these 
patients and cooling produces repetitive spontaneous motor unit discharges with a decrement in the compound muscle action potential (CMAP) amplitude. The clinical features are summarised in table 3.

Paramyotonia congenita is caused by mutations in the voltage gated skeletal muscle sodium channel $\alpha$-subunit $(\mathrm{SCN} 4 \mathrm{~A})^{7}$ on chromosome $17 \mathrm{q} 35$. Voltage dependent activation of this channel results in influx of sodium into the muscle fibre and is therefore responsible for the upstroke of the action potential. Rapid closure of this channel after activation is critical for muscle fibre repolarisation. Paramyotonia congenita is inherited as a highly penetrant autosomal dominant trait. Mutations have been found throughout the gene, although exon 24 appears to be a hotspot for mutations. ${ }^{8}$ Mild depolarisation $(>5 \mathrm{mV})$ produces repetitive discharges (myotonia) while more severe depolarisation $(>20 \mathrm{mV}$ ) produces weakness, either of which may occur as an isolated phenomenon.

\section{Treatment}

The myotonia usually responds to antiarrhythmic drugs such as mexilitine. ' The weakness is potassium sensitive and responds to hydrochlorthiazide, acetazolamide or dichlorphenamide, with or without potassium supplementation.

\section{Differential diagnosis of myotonia}

See table 4 for the differential diagnosis of myotonia.

Many rheumatological conditions may associate with the symptom of muscle stiffness. There are usually associated clinical clues that point to the correct diagnosis such as joint pains. In our experience some cases diagnosed with chronic fatigue or fibromylagia have turned out to have myotonic disorders such as myotonia congenita, emphasising the need for careful clinical and electromyography assessment in such cases. A differential diagnosis of neurological conditions resulting in muscle stiffness is given in table 4 .

\section{Periodic paralyses}

Hyperkalaemic periodic paralysis

Hyperkalaemic periodic paralysis (HyperKPP) is an autosomal dominant disorder with an estimated prevalence of 1:200 000. Patients experience attacks of either focal or generalised muscle weakness often after exercise. Attacks may vary in severity from mild weakness to total paralysis. The duration of attacks is shorter than in hypokalaemic periodic paralysis (HypoKPP) and typically lasts about an hour or two. The attack frequency declines with age but patients often develop a fixed myopathy of variable severity. The clinical features are shown in table 5. It is notable that death is fortunately extremely rare in HyperKPP or HypoKPP. In contrast to Andersen's syndrome (see below), cardiac arrhythmias are uncommon, as the ion channels mutated in HyperPP and HypoKPP are not expressed in cardiac muscle. HyperKPP is caused by point mutations in the skeletal muscle sodium channel $\alpha$-subunit, SCN4A (which is mutated in paramyotonia congenita). ${ }^{10}$ These mutations lead to defective inactivation of the channel. ${ }^{11}$ Some genotype/phenotype correlations can be made. For example, the most frequent point mutation, T704M, which occurs in $60 \%$ of cases frequently leads to permanent late onset muscle weakness. Another frequent mutation, I1592M, is often associated with myotonia in addition to paralysis.

Attacks of weakness are associated with high serum potassium and high urinary potassium excretion. However, it is important to note that the serum potassium may remain within the normal range and that hyperkalaemia may rapidly autocorrect, therefore measurement as early as possible during an attack is critical. The creatine kinase may be normal or modestly increased to about 300 U/l. Many attacks are brief and do not require treatment. If necessary, acute attacks can be terminated by ingestion of carbohydrate or inhaled salbutamol. ${ }^{12}$ Preventative treatment with acetazolamide or a thiazide diuretic may be required. ${ }^{13}$ HyperKPP caused by a mutation in the potassium channel, KCNE3, has been reported only in one family. ${ }^{14}$

\section{Andersen's syndrome}

Andersen's syndrome is an autosomal dominant potassium sensitive periodic paralysis with ventricular dysrhythmias and dysmorphic features. ${ }^{15}$ The dysmorphic features are often subtle but include low set ears, hypertelorism, clinodactyly, and syndactyly. Bidirectional ventricular tachycardia is a frequent and potentially serious arrhythmia. From a practical point of view, this disorder should be considered in any case of periodic paralysis with arrhythmia. The resting electrocardiogram often shows bigeminy. The clinical features are

Table 4 Differential diagnosis of neurological conditions that may mimic myotonia

\begin{tabular}{|c|c|c|c|}
\hline $\begin{array}{l}\text { Region } \\
\text { affected }\end{array}$ & Process & Disease & Discriminatory features \\
\hline $\begin{array}{l}\text { Central } \\
\text { nervous system }\end{array}$ & Dystonia & $\begin{array}{l}\text { Idiopathic torsion dystonia, } \\
\text { task specific dystonia }\end{array}$ & $\begin{array}{l}\text { Leads to sustained abnormal posture of } \\
\text { affected limb }\end{array}$ \\
\hline \multirow[t]{2}{*}{$\begin{array}{l}\text { Peripheral } \\
\text { nervous system }\end{array}$} & & Neuromyotonia & $\begin{array}{l}\text { Isaac's syndrome: see text. Stiffness is } \\
\text { present at rest, increased on muscle } \\
\text { contraction. Fine muscle twitching may be } \\
\text { visible. May be hyporeflexic, autonomic } \\
\text { features common. EMG distinguishes from } \\
\text { myotonia }\end{array}$ \\
\hline & & Benign cramps & $\begin{array}{l}\text { Occur with exercise, stretching overcomes } \\
\text { spasms. EMG distinguishes }\end{array}$ \\
\hline \multirow[t]{4}{*}{ Muscle } & Myotonia & Myotonia congenita, PMC & See text \\
\hline & $\begin{array}{l}\text { Metabolic } \\
\text { muscle disease }\end{array}$ & $\begin{array}{l}\text { McArdle's disease, } \\
\text { phosphofructokinase } \\
\text { deficiency. Other inborn } \\
\text { errors of metabolism }\end{array}$ & $\begin{array}{l}\text { Myalgia, myoglobinuria and spasms leading } \\
\text { to contraction "cramps" of affected muscle } \\
\text { after or during exercise. May also have } \\
\text { painful contractures (hardening of areas }\end{array}$ \\
\hline & $\begin{array}{l}\text { Rippling } \\
\text { muscle disease }\end{array}$ & & $\begin{array}{l}\text { Cramps especially after exercise, myalgia in } \\
\text { legs more than arms, stiffness, characteristic } \\
\text { rippling of musculature, EMG-silent }\end{array}$ \\
\hline & Myopathy & Hypothyroid myopathy & $\begin{array}{l}\text { Stiffness, spasms, hyporeflexia, proximal } \\
\text { weakness, clinical features of hypothyroidism }\end{array}$ \\
\hline
\end{tabular}

EMG, electromyography; PMC, paramyotonia congenita. 
Table 5 Clinical features of the periodic paralyses

\begin{tabular}{|c|c|c|}
\hline & Hyperkalaemic periodic paralysis & Hypokalaemic periodic paralysis \\
\hline Inheritance & Autosomal dominant & Autosomal dominant \\
\hline Age of onset & $\begin{array}{l}\text { First decade, attacks increase in } \\
\text { frequency and severity until age } \\
50 \text { when they decline }\end{array}$ & $\begin{array}{l}\text { Second decade, the frequency of attacks is } \\
\text { maximal between } 15 \text { and } 35 \text { years of age } \\
\text { and then decreases with age }\end{array}$ \\
\hline $\begin{array}{l}\text { Exacerbating } \\
\text { factors }\end{array}$ & $\begin{array}{l}\text { Rest after exercise, cold, potassium } \\
\text { loading, pregnancy, glucocorticoids, } \\
\text { stress, ethanol, fasting (for example, } \\
\text { early morning before breakfast) }\end{array}$ & $\begin{array}{l}\text { Rest after exercise, cold, carbohydrate } \\
\text { loading, menstruation }\end{array}$ \\
\hline $\begin{array}{l}\text { Distribution } \\
\text { of weakness }\end{array}$ & $\begin{array}{l}\text { Usually proximal and symmetric, } \\
\text { flaccid; occasionally distal and } \\
\text { asymmetric in exercised muscles }\end{array}$ & $\begin{array}{l}\text { Paraparesis or tetraparesis, sparing cardiac, } \\
\text { respiratory and facial musculature }\end{array}$ \\
\hline $\begin{array}{l}\text { Duration of } \\
\text { attack }\end{array}$ & $\begin{array}{l}\text { Minutes to hours. More frequent } \\
\text { than in HypoKPP }\end{array}$ & Hours to days \\
\hline Severity & Mild/moderate weakness, can be focal & Moderate/severe weakness \\
\hline $\begin{array}{l}\text { Additional } \\
\text { features }\end{array}$ & $\begin{array}{l}\text { May be associated with paraesthesiae } \\
\text { before paralysis. Tendon reflexes are } \\
\text { abnormally diminished or absent during } \\
\text { the period of paralysis. Many older } \\
\text { patients develop a chronic progressive } \\
\text { myopathy with permanent weakness } \\
\text { that may go unrecognised, this mainly } \\
\text { affects the pelvic girdle and proximal } \\
\text { and distal lower limb muscles. Myotonia } \\
\text { or paramyotonia in around half of cases }\end{array}$ & $\begin{array}{l}\text { A myopathic form results in a progressive } \\
\text { fixed weakness predominantly in the lower } \\
\text { limbs, which occurs in about } 25 \% \text { of patients. } \\
\text { This is independent of paralytic symptoms and } \\
\text { may even be the sole manifestation of the } \\
\text { disease. Some mutations predispose to } \\
\text { rhabdomyolysis }\end{array}$ \\
\hline Relieved by & Carbohydrate intake, mild exercise & \\
\hline Serum potassium & High but can be normal & Low, rarely normal \\
\hline EMG findings & Some have myotonic discharges & None \\
\hline Acute treatment & Inhaled salbutamol ${ }^{12}$ & $\begin{array}{l}\text { Oral potassium, if unable to take oral } \\
\text { preparations, intravenous potassium can be } \\
\text { given, diluted in mannitol }{ }^{4}\end{array}$ \\
\hline $\begin{array}{l}\text { Preventative } \\
\text { therapy }\end{array}$ & Acetazolamide, ${ }^{75}$ thiazide diuretics & $\begin{array}{l}\text { Low sodium/high potassium diet, } \\
\text { dichlorphenamide, }{ }^{76} \text { acetazolamide }\end{array}$ \\
\hline $\begin{array}{l}\text { lon channel } \\
\text { gene }\end{array}$ & $\begin{array}{l}\text { Sodium channel }(\mathrm{SCN} 4 \mathrm{~A})^{10} \\
\text { Potassium channel }(\mathrm{KCNE} 3)^{14}\end{array}$ & $\begin{array}{l}\text { Calcium channel (CACNA1S) })^{19} 20 \\
\text { Sodium channel (SCN4A) }{ }^{21} 22 \\
\text { Potassium channel (KCNE3) })^{14}\end{array}$ \\
\hline
\end{tabular}

summarised in table 6. It is now know that Andersen's syndrome is a cardioskeletal muscle channelopathy caused by mutations in a potassium channel termed Kir2.1. This inward rectifying potassium channel is encoded by KCNJ2 on chromosome 17q23 and disease-causing mutations were first described in 2001. ${ }^{16}$ The channel plays a part in cardiac and skeletal muscle membrane hyperpolarisation and interestingly, also has a role in skeletal bone precursor cell migration and fusion during development, hence the triad of symptoms. Functional expression studies have shown loss of function due to a dominant negative effect on wild-type channel subunits, producing a reduced inwardly rectifying $\mathrm{K}^{+}$current. ${ }^{17}$ There is intrafamilial variability and partial manifestation of the phenotype is common. Serum potassium during an attack may be high, low, or normal. In those with hypokalaemia, oral potassium supplements may improve the weakness. In some families increasing plasma potassium concentration with acetazolamide improves arrhythmias at the expense of exacerbating weakness. ${ }^{18}$ Once the diagnosis is made detailed cardiac assessment is essential. However, the optimum management to prevent malignant arrhythmias is not certain. Currently, opinions vary from imipramine treatment to implantable cardioverter defibrillators.

\section{Hypokalaemic periodic paralysis}

HypoKPP is the most common form of periodic paralysis with an incidence estimated to be one in 100 000. It is inherited in an autosomal dominant manner but new mutations account for up to one third of cases. Comparison with HyperKPP is made in table 5 . The attacks may be brought on by a period of exercise followed by rest or by carbohydrate loading. It is common for attacks to develop in the early hours of the morning, particularly if a large carbohydrate meal was taken late the previous evening. Serum potassium is typically low at the onset but may normalise quickly. However, there is no correlation between serum potassium concentration and the severity of weakness. The creatine kinase is increased during attacks. Conduction velocity in muscle fibres is slow; CMAPs are reduced during attacks and increase immediately after sustained (five minutes) maximal contraction. As in all forms of periodic paralysis attack frequency tends to decline with age but a fixed myopathy may develop. Myotonia never occurs in HypoKPP.

Point mutations in three separate muscle channel genes may cause HypoKPP. The majority of cases harbour one of three point mutations in the L-type calcium channel, CACNAIS. Far less frequent mutations have been described 


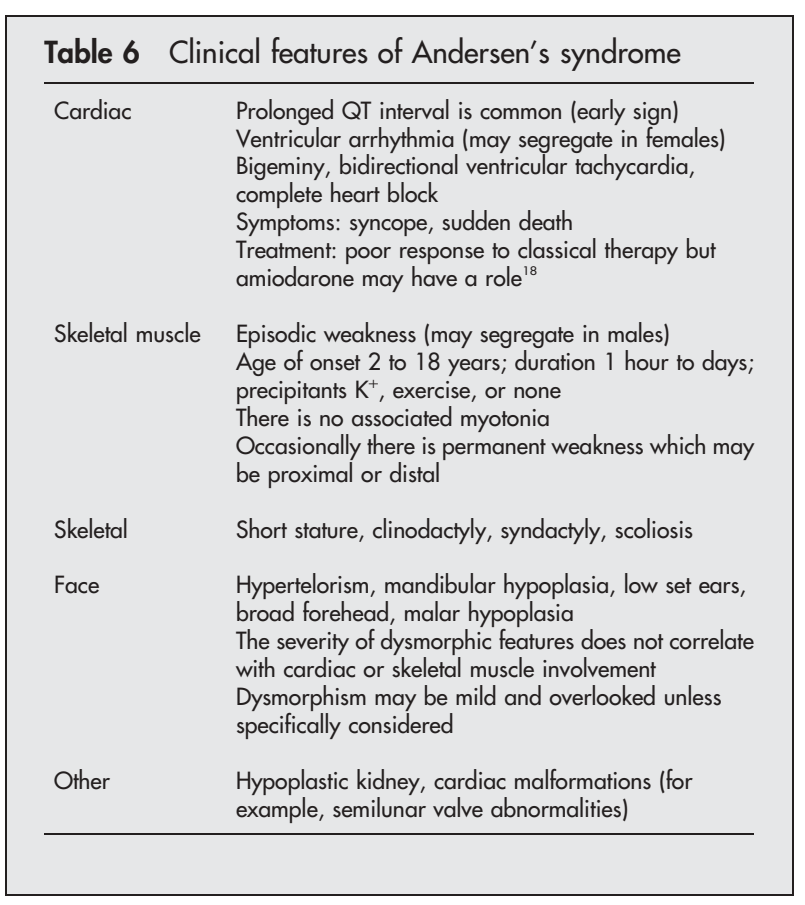

in the muscle sodium channel SCN4A, and in the potassium channel KCNE3. Mutations in the L-type calcium channel $\alpha_{1}$ subunit (dihydropyridine receptor) (CACNAlS), ${ }^{19}{ }^{20}$ located on chromosome 1q31, account for about $70 \%$ of cases of HypoKPP. ${ }^{21}$ All mutations are arginine substitutions in the voltage sensor (S4) of the channel protein. It remains unclear how mutations in CACNAIS, which does not have a major role in determining muscle membrane excitability, result in attacks of paralysis. The normal channel has two roles: (1) as a slow voltage activated calcium channel and (2) excitationcontraction coupling with the ryanodine receptor. Mutated channels have enhanced inactivation leading to a very small defect in the control of muscle resting membrane potential. There is reduced penetrance in females $(50 \%)$ compared with complete penetrance in males. About half of the women who have the R528H mutation and one third of those with the $\mathrm{R} 1239 \mathrm{H}$ mutation are asymptomatic. In contrast, more than $90 \%$ of males with a disease-causing mutation are symptomatic. Specific mutations appear to have discrete clinical features-for example, R528H is common, with later onset and associated myalgias. The other major group of HypoKPP are due to missense mutations in the voltage sensor of domain 2 of SCN4A ${ }^{21} 22$ (the sodium channel affected in HyperKPP and paramyotonia congenita). There is some genotype/phenotype correlation-for example, acetazolamide treatment is often deleterious in the R672G mutation. SCN4A mutations are an uncommon cause of HypoKPP in the UK. ${ }^{23}$ Mutations in KCNE3 on chromosome 11q13-q14 have only been reported in one family. ${ }^{14}$

\section{Practical approach to suspected periodic paralysis}

A high index of suspicion, an accurate history, neurological examination during an attack, and measurement of serum potassium in a sample taken as early as possible after presentation are the keys to making the diagnosis of periodic paralysis. HypoKPP can also occur in the context of hyperthyroidism (usually in Asian patients), ${ }^{24}$ so thyroid function tests should also be measured. Other general medical causes of altered potassium concentrations should always be sought. Associated features which support the suspicion of genetic periodic paralysis may include dysmorphic features (Andersen's syndrome) and myotonia or paramyotonia. Generally we find provocative tests, such as potassium loading or induction of hypokalaemia, unhelpful and they are potentially hazardous. DNA testing should be considered at an early stage with the patient's consent (see end of article for details). If diagnostic uncertainty remains referral to a specialist centre should be considered.

\section{Malignant hyperthermia syndromes}

Malignant hyperthermia syndrome is the most common cause of death during anaesthesia, with an estimated incidence of somewhere between one in 7000 to one in 50000 of anaesthetics given. There is an increased incidence when depolarising muscle relaxants are used in combination with inhaled volatile gases. ${ }^{25}$ It is more prevalent in children, with approximately $50 \%$ of cases occurring before the age of 15 . Table 7 shows the clinical features. Susceptibility tests (mainly the in vitro contraction test) may be diagnostic and can be applied to family members after an affected individual has been identified. The in vitro contraction test requires a large fresh muscle biopsy after which either halothane or caffeine may be applied and the maximal contraction measured.

Disordered muscle calcium regulation is now known to underlie the pathophysiology of malignant hyperthermia syndromes. A trigger (for example, general anaesthesia) leads to excessive activation of the ryanodine receptor calcium release channel and thus calcium is released from sarcoplasmic reticulum stores. Calcium reuptake from the cytoplasm may also be impaired. The increased cytoplasmic calcium leads to excessive muscle contraction, hypermetabolism, rhabdomyolysis, and fever. ${ }^{26}$ Dantrolene inhibits release of calcium from sarcoplasmic reticulum ${ }^{27}$ and early administration has reduced the mortality rate from $70 \%$ to approximately $10 \%$. Mutations in the ryanodine receptor (RYR1) on chromosome $19 \mathrm{ql}^{28}$ are found in $50 \%$ of families with

\begin{tabular}{|c|c|}
\hline Skeletal muscle & $\begin{array}{l}\text { Rigidity and weakness } \\
\text { Rhabdomyolysis } \\
\text { Muscle spasms especially affecting masseter, but can } \\
\text { be generalised } \\
\text { Myalgia }\end{array}$ \\
\hline Autonomic & $\begin{array}{l}\text { Sympathetic overactivity } \\
\text { Hyperventilation } \\
\text { Tachycardia } \\
\text { Haemodynamic instability } \\
\text { Cardiac arrhythmia }\end{array}$ \\
\hline General & $\begin{array}{l}\text { Fever (may be a late sign) } \\
\text { Cyanosis }\end{array}$ \\
\hline Laboratory & $\begin{array}{l}\text { Increased oxygen consumption } \\
\text { Hypercapnia } \\
\text { Lactic acidosis } \\
\text { Raised creatine kinase } \\
\text { Hyperkalaemia }\end{array}$ \\
\hline Triggers & $\begin{array}{l}\text { Full episodes: general anaesthesia (inhalational } \\
\text { agents - isoflurane, desflurane, enflurane, } \\
\text { sevoflurane, methoflurane and halothane), } \\
\text { suxamethonium } \\
\text { Milder malignant hyperthermia: exercise in hot } \\
\text { conditions, neuroleptic drugs, alcohol, infections }\end{array}$ \\
\hline Treatment & $\begin{array}{l}\text { Dantrolene } 2 \mathrm{mg} / \mathrm{kg} \text { intravenously every } 5 \text { minutes to } \\
\text { a total of } 10 \mathrm{mg} / \mathrm{kg} \\
\text { Hyperventilation with supplemental oxygen } \\
\text { Sodium bicarbonate } \\
\text { Active cooling } \\
\text { Discontinue anaesthesia } \\
\text { Maintain urine output over } 2 \mathrm{ml} / \mathrm{kg} / \text { hour } \\
\text { Avoid calcium, calcium antagonists, } \beta \text {-blockers }\end{array}$ \\
\hline
\end{tabular}


malignant hyperthermia and $20 \%$ of all patients with malignant hyperthermia. So far over 30 mutations have been identified, most are missense and 50\% lie between exons 39 to $46 .{ }^{29}{ }^{30}$ However, there is genetic heterogeneity, ${ }^{31}$ with at least five dominantly inherited susceptibility loci identified. These include (1) the sodium channel $\alpha_{1}$-subunit (SCN4A), ${ }^{32}$ allelic with HyperKPP, (2) the skeletal muscle voltage dependent L-type calcium channel (dihydropyridine receptor) $\alpha_{2} / \delta$-subunit (CACNL2A), ${ }^{33}$ (3) the L-type calcium channel (dihydropyridine receptor) $\alpha_{1}$-subunit (CACNAlS), ${ }^{35}$ allelic with HypoKPP, and (4) unknown genes located on chromosome 3q13.1 (MHS4) ${ }^{36}$ and chromosome $5 \mathrm{p}$ (MHS6). ${ }^{37}$ There are also several other primary muscle disorders with an associated susceptibility to an malignant hyperthermia-like reaction. The term malignant hyperthermia-like is used to indicate that these patients may develop the symptom complex very similar to that described in malignant hyperthermia but in these cases there is not a primary disturbance of muscle calcium handling-that is, they do not have RyR mutations. It is suspected that they have a tendency to a disturbance of calcium handing which seems to be secondary to their primary disease. These include myotonia congenita, periodic paralysis, myotonic dystrophy type I, Duchenne and Becker muscular dystrophy, mitochondrial disorders, carnitine palmitoyl-transferase deficiency, and Brody's myopathy. Caution in relation to anaesthesia is therefore advised in patients in all these groups. We advise all patients with these disorders to ensure their anaesthetist and surgeon is aware of the potential for a malignant hyperthermia-like reaction. Similar anaesthetic precautions can then be taken for this patient group.

\section{Central core disease (malignant hyperthermia syndrome 1)}

This is a congenital myopathy with susceptibility to malignant hyperthermia. The clinical features include a nonprogressive myopathy with facial and proximal weakness and hypotonia. Occasionally muscle cramps after exercise are seen. More than a quarter of patients with central core disease have a tendency to malignant hyperthermia, however around $40 \%$ of cases at risk for malignant hyperthermia are asymptomatic. In such cases adequate precautions before anaesthesia are impossible. Central core disease is characterised pathologically by the presence of central core lesion throughout the length of type I muscle fibres. Missense mutations in the skeletal muscle ryanodine receptor gene (RYRl) have been identified in some families with central core disease. ${ }^{38}$

\section{Investigation after an episode of malignant hyperthermia}

A full blown case of malignant hyperthermia is usually a dramatic clinical presentation familiar to anaesthetists. Confirmation of susceptibility to recurrent attacks after such a full attack can be achieved in specialist centres by the in vitro contraction test in combination with genetic testing.

It is very important to screen family members related to any individual who has had such a full blown attack. This must include a careful history, including symptoms of muscle disease-for example, cramps, myalgia, fatigue, myoglobinuria-family history of anaesthetic complications, and measurement of baseline creatine kinase and urine examination for myoglobinuria. Referral to a centre where muscle biopsy, in vitro contraction test, and genetic testing are available is usually required to be certain about status of potentially at risk family members. In the interim, all at risk relatives should be warned of a possible increased risk of malignant hyperthermia under general anaesthesia and be advised to inform their surgeon and anaesthetist. Non-urgent surgery should be postponed until the diagnosis is clarified. However, general anaesthesia can be safely administered if the anaesthetist is aware of the risk and the proper precautions are instituted. Patients should be advised to wear a Medic-alert bracelet.

\section{Neuromuscular junction}

\section{Congenital myasthenic syndromes}

There are several rare congenital myasthenic syndromes due to defects in the key processes that underlie efficient neuromuscular junction transmission. The commonest are mutations in the subunits of the postsynaptic acetylcholine receptor. These myasthenic syndromes may therefore be considered to be genetic ligand gated channelopathies. A detailed summary is beyond the scope of this review, but interested readers are directed to the review by Engel et al. ${ }^{39}$

\section{Central nervous system}

In the last few years an increasing number of genetic CNS channelopathies have been described. Although the starting point for many of these studies were individual families with rare syndromes (for example, familial hemiplegic migraine or benign familial neonatal convulsions), there is increasing evidence that the discoveries made will be relevant to common neurological diseases such as migraine and epilepsy. Perhaps the best evidence that ion channel dysfunction is important in common neurological disease is the recent evidence in epilepsy described below. It has been shown that a particular epilepsy phenotype know as "generalised epilepsy with febrile seizures" is more common than previously realised and that it frequently associates with mutations in brain ion channel genes.

\section{Familial hemiplegic migraine}

Familial hemiplegic migraine is a form of migraine with aura which is inherited in an autosomal dominant manner. Patients experience typical migraine headaches but in addition there are paroxysmal neurological symptoms of aura including hemianopia, hemisensory loss, and dysphasia. Hemiparesis occurs with at least one other symptom during familial hemiplegic migraine aura; the weakness can be prolonged and may outlast the associated migrainous headache by days. Coma has also been described with severe attacks. Persistent attention deficits and memory loss can last weeks to months. Triggers include emotion or head injury. The age at onset for familial hemiplegic migraine is often earlier than typical migraine, frequently beginning in the first or second decade. The number of attacks tends to decrease with age. About $20 \%$ of families have cerebellar signs ranging from nystagmus to progressive, usually late onset cerebellar ataxia. ${ }^{40}$ Genetic studies have established that many cases of familial hemiplegic migraine are caused by missense mutations in the P/Q-type voltage gated calcium channel gene, CACNAlA. ${ }^{41}$ The presynaptic location of this calcium channel allows it to function as a key controller and modulator of the release of both excitatory and inhibitory neurotransmitters throughout the CNS. It is suspected that a disturbance in this control is important in the genesis of familial hemiplegic migraine.

\section{Episodic ataxia}

The episodic ataxias are rare autosomal dominant CNS disorders in which the main clinical features are episodes of profound cerebellar ataxia. The clinical features of episodic ataxias type 1 and 2 are summarised in table 8 .

In patients with episodic ataxia type lexperiences very brief episodes of sudden onset ataxia that may be precipitated by sudden movement or emotion. There may be multiple attacks in a day. Cerebellar function is normal between attacks but there is persistent myokymia or neuromyotonia of 


\begin{tabular}{|c|c|c|}
\hline & Episodic ataxia type 1 & Episodic ataxia type 2 \\
\hline Mode of inheritance & Autosomal dominant & Autosomal dominant \\
\hline Age of onset & Second decade & Early childhood to teens \\
\hline Clinical features & $\begin{array}{l}\text { Ataxia } \\
\text { Dizziness without vertigo } \\
\text { Visual blurring } \\
\text { No nystagmus }\end{array}$ & $\begin{array}{l}\text { Ataxia, truncal instability which may } \\
\text { persist between attacks, dysarthria, } \\
\text { nystagmus } \\
\text { Associated with vertigo, nausea, } \\
\text { vomiting, and headache } \\
\text { Weakness may occur during spells } \\
\text { and can precede onset of episodic } \\
\text { ataxia }\end{array}$ \\
\hline Exacerbating factors & $\begin{array}{l}\text { Abrupt postural change, emotion, startle, } \\
\text { vestibular stimulation }\end{array}$ & Physical or emotional stress \\
\hline Duration of attack & Brief, attacks last minutes & $\begin{array}{l}\text { Aftacks often last } 30 \text { minutes to } \\
>24 \text { hours }\end{array}$ \\
\hline Additional features & $\begin{array}{l}\text { Neuromyotonia (continuous spontaneous } \\
\text { muscle fibre activity) or myokymia occur } \\
\text { during and between episodes of ataxia } \\
\text { Some patients have hyperhidrosis and } \\
\text { seizures }^{88}\end{array}$ & $\begin{array}{l}\text { Downbeating gaze evoked } \\
\text { nystagmus in all directions between } \\
\text { episodes. Impaired vestibulo-ocular } \\
\text { reflex, OKN and smooth pursuits. } \\
\text { Some patients develop progressive } \\
\text { cerebellar atrophy }{ }^{45}\end{array}$ \\
\hline Treatment & Phenyłoin, carbamazepine, not acetazolamide & Acetazolamide \\
\hline lon channel gene & Potassium: $\mathrm{KCNA}^{42-44}$ & $\begin{array}{l}\text { Calcium: CACNA1A, }{ }^{40} \text { allelic with } \\
\text { FHM and SCA } 6{ }^{40}\end{array}$ \\
\hline
\end{tabular}

skeletal muscles. Clinically, this may be observed as fine twitching movements around the eyes or in the limbs. This often produces involuntary fine side-to-side movements of the fingers in the outstretched hands. The myokymia/ neuromyotonia is clinically and electrophysiologically indistinguishable from that seen in the autoimmune potassium channelopathy Isaac's syndrome (see below). Episodic ataxia type 1 is caused by mutations in the potassium channel gene $\mathrm{KCNAl}^{42-44}$ which is expressed both in the cerebellum and at the neuromuscular junction, hence the combination of clinical features.

Episodic ataxia type 2 is characterised by prolonged attacks of cerebellar ataxia. The patient is profoundly ataxic and often has a prominent headache and a feeling of vertigo and nausea. It is probable that many patients previously labelled as having basilar migraine in fact have episodic ataxia type 2 . Attacks are precipitated most commonly by emotion and occasionally by intercurrent illness. The attack frequency declines with age but some patients develop a progressive cerebellar syndrome. ${ }^{45}$ Attacks are often successfully prevented with acetazolamide treatment. Mutations in the voltage gated calcium channel, CACNAlA, cause episodic ataxia type $2 .^{40}$

\section{Calcium channel allelic disorders familial hemiplegic migraine, episodic ataxia type 2, spinocerebellar ataxia type 6: molecular mechanisms}

In addition to familial hemiplegic migraine and episodic ataxia type 2 described above a third disorder known as spinocerebellar ataxia type 6 (SCA6) has also been shown to associate with a mutation in the same calcium channel gene CACNAIA. SCA6 is a late onset autosomal dominant progressive pure cerebellar ataxia and typically associates with a trinucleotide repeat expansion in the region of the gene coding for $\mathrm{C}$ terminal of the calcium channel protein (that is, an expansion of a CAG repeat normally present in the $\mathrm{C}$ terminal region of the gene) ${ }^{41}{ }^{45}$
It is therefore evident that familial hemiplegic migraine, episodic ataxia type 2, and SCA6 are different clinical phenotypes caused by mutations in the same gene-that is, they represent allelic disorders. Although there are some genotype phenotype correlations, there is also overlap. Furthermore, the precise molecular mechanisms underlying the different phenotypes are not elucidated. Some general, although not absolute, observations are emerging and are briefly outlined below.

Familial hemiplegic migraine most frequently associates with missense mutations in CACNAlA. Expression studies have shown various consequences of these missense mutations on channel function but broadly speaking an alteration in channel kinetics is observed. Both an increase and a decrease in channel kinetics have been reported making it difficult to produce a unifying hypothesis for the genesis of the migraine attacks. ${ }^{41}$

Episodic ataxia type 2 most commonly associates with point mutations in CACNAlA which are predicted to truncate the calcium channel protein. Expression studies have pointed to a loss of function and haploinsufficiency as the basis of the attacks. ${ }^{45}$

SCA6 virtually always associates with a CAG repeat expansion in CACNAlA as described above. Unlike other CAG repeat expansions observed in neurogenetic diseases such as in Huntington's disease the SCA6 expansion is relatively stable on transmission and the phenomenon of clinical anticipation (that is, the worsening of disease severity as judged by earlier age at onset in succeeding generations frequently observed in Huntington's disease) is not observed in SCA6. Evidence has been produced that the SCA6 expansion may not only reduce calcium channel function but, as reported in other neurological trinucleotide repeat diseases, may result in abnormal aggregation of calcium channel protein harbouring expanded glutamine tracts coded for by the CAG repeat.

Exceptions to these general observations apply both at a clinical as well as expression level. For example, there are 
missense mutations described which cause a pure progressive ataxia without familial hemiplegic migraine or episodic ataxia type 2 features. Furthermore an episodic ataxia type 2 phenotype has been reported in patients harbouring the SCA6 expansion. Further study of molecular mechanisms is clearly required.

\section{Hyperekplexia}

Hyperekplexia is characterised by onset at birth with hypertonia that disappears in sleep, exaggerated startle response, and strong brainstem reflexes (especially the head retraction reflex). The exaggerated startle reaction occurring after sudden, unexpected acoustic or tactile stimuli persists into adulthood and is associated with involuntary myoclonus (occasionally resulting in falls) and marked nocturnal myoclonic jerks. Continuous and occasionally fatal muscular rigidity is also a feature. Electromyography shows continuous motor unit activity. The GLRAl gene (encoding the glycine receptor $\alpha_{1}$-subunit, a ligand gated ion channel) was the first gene for a neurotransmitter receptor in the CNS to be identified as the site of mutation in a human disorder ${ }^{46}$ Cases are usually autosomal dominant, but some recessive pedigrees have been reported.

\section{Andermann's syndrome}

Andermann's syndrome is an autosomal recessive hereditary motor and sensory neuropathy with agenesis of the corpus callosum. This is found at high frequency ( $1: 2100$ live births) in the province of Quebec in Canada. Mutations impair function of the potassium-chloride co-transporter, KCC3 found in the brain and spinal cord encoded by SLC12A6 ${ }^{47}$ on chromosome 15q13-q15. There is symmetric or asymmetric involvement of the cranial nerves with ptosis, facial weakness, ophthalmoplegia (reduced upgaze), and optic atrophy. Motor neuropathy presents early with hypotonia and severe progressive global weakness; affected patients rarely walk independently. Sensory loss is manifest as areflexia and tremor. Involvement of the CNS is seen as mental retardation, seizures, and atypical psychosis with onset in the teens. Dysmorphic features include long facies, hypertelorism, brachycephaly, high arched palate, syndactyly of the second and third toes, and overriding the first toe. Scoliosis may lead to a restrictive lung defect. There is partial or complete agenesis of the corpus callosum due to a defect in axon migration across the midline.

\section{Inherited epilepsy syndromes}

There are several inherited epilepsy syndromes which are genetic channelopathies. Here we discuss four of these.

\section{Benign familial neonatal convulsion}

This is an autosomal dominant disorder characterised by brief generalised seizures that clear spontaneously after the age of 6 weeks, with no neuropsychological morbidity. Knowledge of this disorder can prevent needless and potentially harmful anticonvulsive therapy. It is now established that benign familial neonatal convulsion is a CNS potassium channelopathy. Highly penetrant mutations in the KCNQ2 gene ${ }^{48}{ }^{49}$ on chromosome 20 and KCNQ3 gene $^{50}$ on chromosome 8 have been found in pedigrees with benign familial neonatal convulsion.

\section{Generalised epilepsy with febrile seizures plus syndrome}

One of the most important genetic epilepsy discoveries in recent years has been the identification of the generalised epilepsy with febrile seizures plus syndrome phenotype. ${ }^{51}$ This is a pleomorphic familial epilepsy syndrome that may include febrile and afebrile generalised tonic-clonic, absence, myoclonic, and atonic seizures. Any combination of seizures may be observed in a given family. There are now a significant number of such families described worldwide. Generalised epilepsy with febrile seizures plus syndrome has been found to be genetically heterogeneous, but in all cases disturbed ion channel function has been found to be the basis of the disease. Mutations have been described in the voltage gated sodium channel $\beta_{1}$-subunit gene (SCN1B) ${ }^{52}{ }^{53}$; voltage gated sodium channel $\alpha_{1}$-subunit gene $(\mathrm{SCNlA})^{54}$; GABA receptor $\gamma_{2}$-subunit gene $(\mathrm{GABRG} 2)^{55}{ }^{56}$; and the voltage gated sodium channel type II $\alpha_{1}$-subunit gene (SCNA2A). ${ }^{57}$ It has been shown that increased neuronal excitability due to the mutant channels is predicted to lead to epileptogenesis. Since the possible epilepsy phenotypes that may occur in these families with normal neuroimaging are indistinguishable from many common epilepsy phenotypes, many workers are now undertaking studies to establish if variations in these channel genes are important in determining susceptibility to common forms of epilepsy.

Autosomal dominant nocturnal frontal lobe epilepsy This is characterised by focal onset frontal lobe seizures, almost exclusive occurrence during drowsiness or sleep, and variable severity of symptoms in family members. Milder cases are often undiagnosed or misdiagnosed as nightmares, parasomnias, or functional disorders. Neuroimaging is normal and treatment with carbamazepine is dramatically effective. Although recognition of this syndrome is important for appropriate therapy and genetic counselling, underestimation of cases is likely. The clinical delineation of this as a separate disorder allowed genetic analysis to be performed. ${ }^{58}$ Mutations have been found in the nicotinic acetylcholine receptor $\alpha_{4}$-subunit, CHRNA4 $4^{59}$ and $\beta_{2}$-subunit, CHRNB2 ${ }^{60}$ This is a brain ligand gated ion channel that is mainly presynaptic in location and has a role in controlling neurotransmitter release. Alterations in the balance of excitatory and inhibitory transmitters are suggested to be important in the genesis of seizures.

\section{Childhood absence epilepsy}

Most recently, studies in a large Chinese cohort with childhood absence epilepsy found mutations in the brain Ttype calcium channel CACNAlH. ${ }^{61}$ Functional analysis has shown that two of the mutations allow increased calcium influx during physiological activation and another results in channel opening at more hyperpolarised potentials, which may underlie the propensity for seizures ${ }^{62}$ However, a recent study has failed to replicate these findings in mixed idiopathic generalised epilepsy pedigrees. ${ }^{63}$

\section{AUTOIMMUNE CHANNELOPATHIES}

For comparison to selected genetic channelopathies, see table 9 .

\section{Neuromuscular junction}

Myasthenia gravis is the archetypal autoimmune channelopathy affecting neuromuscular transmission, via the acetylcholine receptor, a ligand gated ion channel. There are many excellent descriptions of this disorder in standard textbooks and we will not consider it further here.

\section{Lambert-Eaton myasthenic syndrome}

Lambert-Eaton myasthenic syndrome (LEMS) is a paraneoplastic disorder in which patients produce antibodies directed against the presynaptic voltage gated P/Q-type calcium channel $\alpha_{1 \mathrm{~A}}$-subunit. Typically, patients experience proximal weakness often in combination with autonomic symptoms. A common finding is absent or diminished tendon reflexes which reappear after brief maximal voluntary contraction or 


\begin{tabular}{|c|c|c|c|c|}
\hline lon channel & $\begin{array}{l}\text { Genetic } \\
\text { disease }\end{array}$ & Clinical features & $\begin{array}{l}\text { Autoimmune } \\
\text { disease }\end{array}$ & Clinical features \\
\hline \multirow[t]{2}{*}{$\begin{array}{l}\text { P/Q-type voltage } \\
\text { gated calcium } \\
\text { channel }\end{array}$} & $\begin{array}{l}\mathrm{FHM} \\
\mathrm{EA} 2\end{array}$ & $\begin{array}{l}\text { Migraine } \\
\text { Paroxysmal ataxia, } \\
\text { some with progressive } \\
\text { cerebellar ataxia }\end{array}$ & LEMS & $\begin{array}{l}\text { Weakness, some } \\
\text { associated with ataxia } \\
\text { (PCD) }\end{array}$ \\
\hline & SCA6 & $\begin{array}{l}\text { Progressive cerebellar } \\
\text { ataxia }\end{array}$ & PCD & $\begin{array}{l}\text { Progressive cerebellar } \\
\text { ataxia }\end{array}$ \\
\hline $\begin{array}{l}\text { Potassium channel: } \\
\mathrm{K}_{\mathrm{v}} 1.1(\mathrm{EA} 1), \mathrm{K}_{\mathrm{v}} 1.2 \\
\text { (autoimmune) }\end{array}$ & EA1 & $\begin{array}{l}\text { Paroxysmal ataxia, } \\
\text { myokymia, associated } \\
\text { with seizures, some } \\
\text { have hyperhidrosis }\end{array}$ & $\begin{array}{l}\text { Isaac's syndrome, } \\
\text { Morvan's } \\
\text { syndrome }\end{array}$ & $\begin{array}{l}\text { Neuromyotonia, } \\
\text { hyperhidrosis. As above } \\
\text { plus psychiatric symptoms } \\
\text { (LE) and seizures }\end{array}$ \\
\hline $\begin{array}{l}\text { Acetylcholine } \\
\text { receptor subunits }\end{array}$ & $\begin{array}{l}\text { Congenital } \\
\text { myasthenic } \\
\text { syndromes }\end{array}$ & Permanent weakness & $\begin{array}{l}\text { Myasthenia } \\
\text { gravis }\end{array}$ & Fluctuant weakness \\
\hline
\end{tabular}

repeated tendon percussion (post-tetanic potentiation). Weakness, when present, almost universally affects the lower limbs. The upper limbs are frequently affected with involvement of bulbar and respiratory musculature less often. Weakness may be improved with brief exercise and may worsen with sustained exercise, heat, or fever. Fatigability is present in a third of cases. Some patients complain of myalgia. In contrast to myasthenia gravis the extraocular muscles are infrequently involved. There may also be an associated distal, symmetric sensory neuropathy. As in myasthenia gravis, LEMS may occasionally be exacerbated by drugs-for example, neuromuscular blocking agents, antibiotics (aminoglycosides, fluoroquinolones), magnesium, $\mathrm{Ca}^{2+}$ channel blockers, and iodinated intravenous contrast agents. However, in contrast to myasthenia gravis, LEMS never begins with ocular weakness and usually has more marked weakness in legs than in the arms.

Antibody-mediated reduction in the number of presynaptic calcium channels at the nerve terminal leading to reduced acetylcholine release underlies the pathogenesis of LEMS. IgG antibodies against the P/Q-type calcium channel $\alpha_{1 A^{-}}$ subunit (which is mutated in familial hemiplegic migraine, episodic ataxia type 2, and SCA6) are present in over $85 \%$ of cases. ${ }^{64}$ Repetitive nerve stimulation shows an increment after rapid or sustained muscle contraction that is prolonged by cooling muscles. Small cell lung carcinoma (SCLC) is the most frequently associated neoplasm. Indeed, up to 3\% of patients with SCLC have LEMS. Other associations include lymphoproliferative disorders-for example, reticulum cell sarcoma, T-cell leukaemia, lymphoma, and Castleman's disease. The onset of LEMS is usually six months to five years before any neoplasm is detected. However, one third of cases occur in the absence of malignancy at diagnosis and do not seem to develop a tumour even over long term follow up. Such cases may represent primary autoimmune non-paraneoplastic disorders. Treatment is often beneficial, the mainstay being 3,4-diaminopyridine. There may be an associated cerebellar syndrome (see below).

\section{Peripheral nervous system Isaac's syndrome}

Acquired neuromyotonia (Isaac's syndrome) manifests as muscle cramps, slow relaxation of muscles after contraction (pseudomyotonia) and hyperhidrosis. Electromyography shows myokymic and neuromyotonic discharges (repetitive firing at rates of 5-150 Hz and $150-300 \mathrm{~Hz}$ respectively). This spontaneous muscle activity is driven by abnormal firing of peripheral nerves. ${ }^{65}$ Antibodies to voltage gated potassium channels ${ }^{66}$ have been shown to induce hyperexcitability of the nerve by suppressing the outward potassium current. ${ }^{67}$ It is evident that Issac's syndrome is the autoimmune counterpart to genetically determined neuromyotonia. In both situations the same potassium channel is dysfunctional. In Isaac's syndrome this is induced by autoimmune attack, in contrast, in genetic neuromyotonia there is a mutation in the gene for the same potassium channel-that is, the KCNAl gene.

\section{Central nervous system}

Paraneoplastic cerebellar degeneration

Paraneoplastic cerebellar degeneration (PCD) usually presents as a subacute cerebellar syndrome which progresses over weeks to months. There are multiple antineuronal antibodies associated with PCD, the most common of which are anti-Yo in breast and ovarian malignancies and anti-Hu in SCLC. ${ }^{68}$ Some patients with LEMS have also been noted to have cerebellar ataxia, implicating the P/Q-type calcium channel in pathogenesis. This channel is expressed not only by presynaptic PNS nerve terminals but also those in cerebellar Purkinje and granule cells. Postmortem findings in these patients show Purkinje cell loss and cerebellar cortical gliosis. ${ }^{69}$ In one study, $9 \%$ of LEMS patients had coexistent PCD and high titres of anti-P/Q-type voltage gated calcium channel antibodies (the same channel affected in SCA6, familial hemiplegic migraine, and episodic ataxia type 2 ). In another study of PCD, $41 \%$ of patients were found to have anti-P/Q-type voltage gated calcium channel antibodies with accompanying cerebrospinal fluid antibodies. ${ }^{70}$ This paraneoplastic syndrome is most frequently associated with SCLC.

PCD associated with the calcium channel antibodies described may therefore be regarded as the immunological counterpart for episodic ataxia type 2 which associates with point mutations in the same calcium channel CACNAlA. However, from a clinical viewpoint PCD is a much more aggressive, rapidly progressive cerebellar ataxia than episodic ataxia type 2. In PCD we envisage there is progressive destruction and loss of these calcium channels which may account for the clinical severity observed.

\section{Morvan's syndrome}

Limbic encephalitis is a paraneoplastic syndrome associated with SCLC and rarely with other tumour types. The symptoms consist of psychiatric involvement (personality changes, hallucinations, and insomnia), seizures, short term memory loss, and confusion. There is usually hyperintense T2-weighted signal change in the hippocampi and amygdala. The majority of patients with limbic encephalitis have 


\section{Key references}

- Ptacek U, George AL Jr, Griggs RC, et al. Identification of a mutation in the gene causing hyperkalemic periodic paralysis. Cell 1991;67:1021-7. (First neurological channelopathy described.)

- Ophoff RA, Terwindt GM, Vergouwe MN, et al. Familial hemiplegic migraine and episodic ataxia type-2 are caused by mutations in the $\mathrm{Ca}^{2+}$ channel gene CACNL1A4. Cell 1996;87:543-52. (First demonstration that brain calcium channel mutations may cause human neurological disease.)

- Shiang R, Ryan SG, Zhu YZ, et al. Mutations in the alpha 1 subunit of the inhibitory glycine receptor cause the dominant neurologic disorder, hyperekplexia. Nat Genet 1993;5:351-8. (First CNS neurotransmitter receptor implicated in disease.)

- Steinlein OK, Mulley JC, Propping P, et al. A missense mutation in the neuronal nicotinic acetylcholine receptor alpha 4 subunit is associated with autosomal dominant nocturnal frontal lobe epilepsy. Nat Genet 1995;11:201-3. (First epilepsy ion channel mutation.)

associated anti-Hu antibodies. Morvan's syndrome is the association of limbic encephalitis with neuromyotonia, hyperhidrosis, and polyneuropathy. Antibodies to voltage gated potassium channels have been found in the sera and cerebrospinal fluid of these patients. ${ }^{71}$ Reducing the antibody titres with plasma exchange has led to symptomatic improvement. ${ }^{72}$

\section{CONCLUSIONS}

The neurological channelopathies are an important and expanding area within neurology.

It is evident that the PNS and CNS may be affected in isolation or in combination. In addition, it has become clear that either genetic or autoimmune insults to the relevant channel may underlie disease pathogenesis. Indeed, it may well transpire that for each genetic channelopathy there will be its autoimmune counterpart, for examples, see table 9. To date, autoimmune channelopathies affecting the CNS are relatively uncommon but are likely to increase as further antibodies are identified. For example, the true incidence of Morvan's syndrome is not established and it is likely to be under recognised. Furthermore, the role of antibodies directed against the CNS in the genesis of epilepsy has not been fully elucidated. For many channelopathies an accurate genetic or autoimmune diagnosis can be achieved. For muscle genetic channelopathies there is a national centre for diagnosis in the UK. Genetic diagnosis is clearly important in order to allow accurate genetic counselling in appropriate families and will often inform treatment choices. Finally, new insights into the mechanisms of epilepsy and migraine are being gained by the study of genetic channelopathies. It seems probable that genetic susceptibility to common forms of epilepsy and migraine may be determined by variation in ion channel genes, which are critical in determining neuronal excitability.

\section{ACKNOWLEDGEMENTS}

Further information regarding the UK national diagnostic service for muscle channelopathies (NSCAG service) and regarding DNA based diagnosis in neurological genetic channelopathies is available from Dr M G Hanna.

The DNA diagnostic service for muscle channelopathies is supported by the Department of Health National Specialist
Commissioning Agency (NSCAG), UK. Thanks to Dr Everett. Research in our laboratory is supported by the Guarantors of Brain, the Wellcome Trust, the Medical Research Council, and the Special Trustees of University College London Hospitals NHS Trust.

\section{QUESTIONS (TRUE (T)/FALSE (F); ANSWERS AT END OF REFERENCES)}

1. Consider the following statements regarding myotonia congenita:

(A) It may be inherited in either an autosomal dominant or an autosomal recessive fashion

(B) It affects tissues other than skeletal muscle

(C) It is usually unresponsive to antimyotonic agents

(D) It is caused by mutations in a voltage gated sodium channel on chromosome 17

2. Periodic paralysis:

(A) Attacks of weakness are always accompanied by a change in serum potassium concentration

(B) Attack frequency may be reduced by acetazolamide prophylaxis

(C) Patients may develop permanent muscular weakness after a few years of attacks

(D) May be caused by mutations in a ligand gated calcium channel on chromosome 1

\section{Malignant hyperthermia:}

(A) May be caused by mutations in the gene encoding the ryanodine receptor of skeletal muscle

(B) Is characterised by excessive release of calcium from the sarcoplasmic reticulum of skeletal muscle into the skeletal muscle cytoplasm

(C) Is allelic with central core myopathy

(D) Is precipitated by dantrolene therapy

4. Lambert-Eaton myasthenic syndrome:

(A) Is an autoimmune channelopathy caused by antibodies against a postsynaptic voltage gated calcium channel

(B) May be a paraneoplastic disorder frequently associated with carcinoma of the lung

(C) Usually presents after the age of 50 years

(D) May be associated with thymoma

5. Episodic ataxia type 2:

(A) Is characterised by brief ( 1-2 minutes) attacks of ataxia

(B) Is caused by point mutations in the voltage gated calcium channel gene CACNAlA

(C) Is inherited in an autosomal recessive manner

(D) Is rarely responsive to carbonic anhydrase inhibitors

\section{Authors' affiliations}

T D Graves, M G Hanna, Department of Molecular Neuroscience, Institute of Neurology, and Centre for Neuromuscular Disease, National Hospital for Neurology and Neurosurgery, London, UK

\section{REFERENCES}

1 Koch MC, Steinmeyer K, Lorenz C, et al. The skeletal muscle chloride channel in dominant and recessive human myotonia. Science 1992;257:797-800.

2 Kubisch C, Schmidt-Rose T, Fontaine B, et al. ClC-1 chloride channel mutations in myotonia congenita: variable penetrance of mutations shifting the voltage dependence. Hum Mol Genet 1998;7:1753-60.

3 Wu FF, Ryan A, Devaney J, et al. Novel CLCN1 mutations with unique clinical and electrophysiological consequences. Brain 2002;125:2392-407. 
4 Ceccarelli M, Rossi B, Siciliano G, et al. Clinical and electrophysiological reports in a case of early onset myotonia congenita (Thomsen's disease) successfully treated with mexiletine. Acta Paediatr 1992;81:453-5.

5 Ricker K, Moxley RT 3rd, Heine R, et al. Myotonia fluctuans. A third type of muscle sodium channel disease. Arch Neurol 1994;51:1095-102.

6 Ptacek L, Tawil R, Griggs RC, et al. Sodium channel mutations in acetazolamide-responsive myotonia congenita, paramyotonia congenita, and hyperkalemic periodic paralysis. Neurology 1994;44:1500-3.

7 Ptacek LJ, George AL Jr, Barchi RL, et al. Mutations in an S4 segment of the adult skeletal muscle sodium channel cause paramyotonia congenita. Neuron 1992;8:891-7

8 Davies NP, Eunson LH, Gregory RP, et al. Clinical, electrophysiological, and molecular genetic studies in a new family with paramyotonia congenita. J Neurol Neurosurg Psychiatry 2000;68:504-7.

9 Weckbecker K, Wurz A, Mohammadi B, et al. Different effects of mexiletine on two mutant sodium channels causing paramyotonia congenita and hyperkalemic periodic paralysis. Neuromuscul Disord 2000;10:31-9.

10 Ptacek L, George AL Jr, Griggs RC, et al. Identification of a mutation in the gene causing hyperkalemic periodic paralysis. Cell 1991;67:1021-7.

11 Hayward L, Sandoval GM, Cannon SC. Defective slow inactivation of sodium channels contributes to familial periodic paralysis. Neurology 1999:52:1447-53.

12 Hanna MG, Stewart J, Schapira AH, et al. Salbutamol treatment in a patient with hyperkalaemic periodic paralysis due to a mutation in the skeletal muscle sodium channel gene (SCN4A). I Neurol Neurosurg Psychiatry 1998:65:248-50.

13 Hoskins B, Vroom FQ, Jarrell MA. Hyperkalemic periodic paralysis. Effects of potassium, exercise, glucose, and acetazolamide on blood chemistry. Arch Neurol 1975;32:519-23.

14 Abbott GW, Butler MH, Bendahhou S, et al. MiRP2 forms potassium channels in skeletal muscle with $\mathrm{Kv} 3.4$ and is associated with periodic paralysis. Cell 2001;104:217-31.

15 Sansone V, Griggs RC, Meola G, et al. Andersen's syndrome: a distinct periodic paralysis. Ann Neurol 1997;42:305-12

16 Plaster NM, Tawil R, Tristani-Firouzi M, et al. Mutations in Kir2.1 cause the developmental and episodic electrical phenotypes of Andersen's syndrome. Cell 2001;105:511-19.

17 Tristani-Firouzi M, Jensen JL, Donaldson MR, et al. Functional and clinical characterization of KCNJ2 mutations associated with LQT7 (Andersen syndrome). J Clin Invest 2002;1 10:381-8.

18 Junker J, Haverkamp W, Schulze-Bahr E, et al. Amiodarone and acetazolamide for the treatment of genetically confirmed severe Andersen syndrome. Neurology 2002;59:466.

19 Ptacek L, Tawil R, Griggs RC, et al. Dihydropyridine receptor mutations cause hypokalemic periodic paralysis. Cell 1994;77:863-8.

20 Jurkat-Rott K, Lehmann-Horn F, Elbaz A, et al. A calcium channel mutation causing hypokalemic periodic paralysis. Hum Mol Genet 1994;3:1415-19.

21 Sternberg D, Maisonobe T, Jurkat-Rott K, et al. Hypokalaemic periodic paralysis type 2 caused by mutations at codon 672 in the muscle sodium channel gene SCN4A. Brain 2001;124:1091-9.

22 Bulman DE, Scoggan KA, van Oene MD, et al. A novel sodium channel mutation in a family with hypokalemic periodic paralysis. Neurology 1999;53:1932-6.

23 Davies NP, Eunson LH, Samuel M, et al. Sodium channel gene mutations in hypokalemic periodic paralysis: an uncommon cause in the UK. Neurology 2001;57:1323-5.

24 Tran HA, Kay Se, Kende M, et al. Thyrotoxic, hypokalaemic periodic paralysis in Australasian men. Intern Med J 2003;33:91-4.

25 Hogan K. The anesthetic myopathies and malignant hyperthermias. Curr Opin Neurol 1998;11:469-76.

26 Jurkat-Rott K, McCarthy T, Lehmann-Horn F. Genetics and pathogenesis of malignant hyperthermia. Muscle Nerve 2000;23:4-17.

27 Zhao F, Li P, Chen SR, et al. Dantrolene inhibition of ryanodine receptor Ca2+ release channels. Molecular mechanism and isoform selectivity. J Biol Chem 2001;276:13810-16.

28 MacLennan DH, Otsu K, Fujii J, et al. The role of the skeletal muscle ryanodine receptor gene in malignant hyperthermia. Symp Soc Exp Biol 1992;46:189-201.

29 Quane KA, Keating KE, Manning BM, et al. Detection of a novel common mutation in the ryanodine receptor gene in malignant hyperthermia: implications for diagnosis and heterogeneity studies. Hum Mol Genet 1994;3:471-6

30 Manning BM, Quane KA, Ording $\mathrm{H}$, et al. Identification of novel mutations in the ryanodine-receptor gene (RYRI) in malignant hyperthermia: genotypephenotype correlation. Am J Hum Genet 1998;62:599-609.

31 Robinson RL, Curran JL, Ellis FR, et al. Multiple interacting gene products may influence susceptibility to malignant hyperthermia. Ann Hum Genet 2000;64:307-20.

32 Moslehi R, Langlois S, Yam I, et al. Linkage of malignant hyperthermia and hyperkalemic periodic paralysis to the adult skeletal muscle sodium channel (SCN4A) gene in a large pedigree. Am J Med Genet 1998;76:21-7.

33 Iles DE, Lehmann-Horn F, Scherer SW, et al. Localization of the gene encoding the alpha $2 /$ delta-subunits of the L-type voltage-dependent calcium channel to chromosome $7 q$ and analysis of the segregation of flanking markers in malignant hyperthermia susceptible families. Hum Mol Genet 1994;3:969-75.

34 Monnier N, Procaccio V, Stieglitz P, et al. Malignant-hyperthermia susceptibility is associated with a mutation of the alpha 1-subunit of the human dihydropyridine-sensitive L-type voltage-dependent calcium-channel receptor in skeletal muscle. Am J Hum Genet 1997;60:1316-25.
35 Stewart SL, Hogan K, Rosenberg H, et al. Identification of the Arg1086His mutation in the alpha subunit of the voltage-dependent calcium channel (CACNA1S) in a North American family with malignant hyperthermia. Clin Genet 2001:59:178-84.

36 Sudbrak R, Procaccio V, Klausnitzer M, et al. Mapping of a further malignant hyperthermia susceptibility locus to chromosome 3q13.1. Am J Hum Genet 1995;56:684-91.

37 Robinson RL, Monnier N, Wolz W, et al. A genome wide search for susceptibility loci in three European malignant hyperthermia pedigrees. Hum Mol Genet 1997;6:953-61.

38 Monnier N, Romero NB, Lerale J, et al. An autosomal dominant congenital myopathy with cores and rods is associated with a neomutation in the RYR 1 gene encoding the skeletal muscle ryanodine receptor. Hum Mol Genet 2000;9:2599-608

39 Engel AG, Ohno K, Sine SM. Congenital myasthenic syndromes: progress over the past decade. Muscle Nerve 2003;27:4-25.

40 Ophoff RA, Terwindt GM, Vergouwe MN, et al. Familial hemiplegic migraine and episodic ataxia type- 2 are caused by mutations in the $\mathrm{Ca}^{2+}$ channel gene CACNL1A4. Cell 1996;87:543-52

41 Ducros A, Denier C, Joutel A, et al. The clinical spectrum of familial hemiplegic migraine associated with mutations in a neuronal calcium channel. N Engl J Med 2001;345:17-24.

42 Browne DL, Gancher ST, Nutt JG, et al. Episodic ataxia/myokymia syndrome is associated with point mutations in the human potassium channel gene, KCNA1. Nat Genet 1994;8:136-40.

43 Adelman JP, Bond $C T$, Pessia $M$, et al. Episodic ataxia results from voltagedependent potassium channels with altered functions. Neuron 1995; 15:1449-54.

44 Eunson LH, Rea R, Zuberi SM, et al. Clinical, genetic, and expression studies of mutations in the potassium channel gene KCNAl reveal new phenotypic variability. Ann Neurol 2000;48:647-56.

45 Denier C, Ducros A, Vahedi K, et al. High prevalence of CACNA1A truncations and broader clinical spectrum in episodic ataxia type 2. Neurology 1999;52:1816-21.

46 Shiang R, Ryan SG, Zhu YZ, et al. Mutations in the alpha 1 subunit of the inhibitory glycine receptor cause the dominant neurologic disorder, hyperekplexia. Nat Genet 1993;5:351-8.

47 Howard HC, Mount DB, Rochefort D, et al. The $\mathrm{K}-\mathrm{Cl}$ cotransporter KCC3 is mutant in a severe peripheral neuropathy associated with agenesis of the corpus callosum. Nat Genet 2002;32:384-92

48 Biervert C, Schroeder BC, Kubisch C, et al. A potassium channel mutation in neonatal human epilepsy. Science 1998;279:403-6.

49 Singh NA, Charlier C, Stauffer D, et al. A novel potassium channel gene, KCNQ2, is mutated in an inherited epilepsy of newborns. Nat Genet 1998; 18:25-9.

50 Charlier C, Singh NA, Ryan SG, et al. A pore mutation in a novel KQT-like potassium channel gene in an idiopathic epilepsy family. Nat Genet 1998;18:53-5

51 Scheffer IE, Berkovic SF. Generalised epilepsy with febrile seizures plus. A genetic disorder with heterogenous clinical phenotypes. Brain 1997; 120:479-90

52 Wallace RH, Wang DW, Singh R, et al. Febrile seizures and generalized epilepsy associated with a mutation in the $\mathrm{Na}$-channel betal subunit gene SCN1B. Nat Genet 1998; 19:366-70.

53 Audenaert D, Claes L, Ceulemans B, et al. A deletion in SCNIB is associated with febrile seizures and early-onset absence epilepsy. Neurology 2003:61:854-6.

54 Escayg A, MacDonald BT, Meisler MH, et al. Mutations of SCN1A, encoding a neuronal sodium channel, in two families with GEFS+2. Nat Genet 2000;24:343-5.

55 Baulac S, Huberfeld G, Gourfinkel-An I, et al. First genetic evidence of $G A B A(A)$ receptor dysfunction in epilepsy: a mutation in the gamma2-subunit gene. Nat Genet $2001 ; 28: 46-8$.

56 Wallace RH, Marini C, Petrou S, et al. Mutant GABA(A) receptor gamma2subunit in childhood absence epilepsy and febrile seizures. Nat Genet 2001;28:49-52.

57 Sugawara T, Tsurubuchi Y, Agarwala KL, et al. A missense mutation of the $\mathrm{Na}+$ channel alpha II subunit gene $\mathrm{Na}(\mathrm{v}) 1.2$ in a patient with febrile and afebrile seizures causes channel dysfunction. Proc Natl Acad Sci U S A 2001;98:6384-9.

58 Scheffer IE, Bhatia KP, Lopes-Cendes I, et al. Autosomal dominant nocturnal frontal lobe epilepsy. A distinctive clinical disorder. Brain 1995; 118(pt 1):61-73.

59 Steinlein OK, Mulley JC, Propping P, et al. A missense mutation in the neuronal nicotinic acetylcholine receptor alpha 4 subunit is associated with autosomal dominant nocturnal frontal lobe epilepsy. Nat Genet 1995; 11:201-3.

60 De Fusco $M$, Becchetti A, Patrignani $A$, et al. The nicotinic receptor beta 2 subunit is mutant in nocturnal frontal lobe epilepsy. Nat Genet 2000;26:275-6.

61 Chen Y, Lu J, Pan H, et al. Association between genetic variation of CACNA1H and childhood absence epilepsy. Ann Neurol 2003;54:239-43.

62 Khosravani H, Altier C, Simms B, et al. Gating effects of mutations in the Ca 3.2 T-type calcium channel associated with childhood absence epilepsy. J Biol Chem 2004;279:9681-4.

63 Heron SE, Phillips HA, Mulley JC, et al. Genetic variation of CACNA1H in idiopathic generalised epilepsy. Ann Neurol 2004;55:595-6.

64 Nakao YK, Motomura M, Suenaga A, et al. Specificity of omega-conotoxin MVIIC-binding and -blocking calcium channel antibodies in Lambert-Eaton myasthenic syndrome. J Neurol 1999;246:38-44. 
65 Arimura $\mathrm{K}$, Sonoda $\mathrm{Y}$, Watanabe $\mathrm{O}$, et al. Isaacs' syndrome as a potassium channelopathy of the nerve. Muscle Nerve 2002; suppl 11:S55-8.

66 Hart IK, Waters C, Vincent A, et al. Autoantibodies detected to expressed K+ channels are implicated in neuromyotonia. Ann Neurol 1997:41:238-46.

67 Shillito P, Molenaar PC, Vincent A, et al. Acquired neuromyotonia: evidence for autoantibodies directed against $\mathrm{K}+$ channels of peripheral nerves. Ann Neurol 1995;38:714-22.

68 Shams'ili S, Grefkens J, de Leeuw B, et al. Paraneoplastic cerebellar degeneration associated with antineuronal antibodies: analysis of 50 patients. Brain 2003;126:1409-18.

69 Fukuda T, Motomura M, Nakao Y, et al. Reduction of P/Q-type calcium channels in the postmortem cerebellum of paraneoplastic cerebellar degeneration with Lambert-Eaton myasthenic syndrome. Ann Neurol 2003:53:21-8

70 Graus F, Lang B, Pozo-Rosich P, et al. P/Q type calcium-channel antibodies in paraneoplastic cerebellar degeneration with lung cancer. Neurology 2002;59:764-6.

71 Pozo-Rosich P, Clover L, Saiz A, et al. Voltage-gated potassium channel antibodies in limbic encephalitis. Ann Neurol 2003:54:530-3.

72 Liguori R, Vincent A, Clover L, et al. Morvan's syndrome: peripheral and central nervous system and cardiac involvement with antibodies to voltage-gated potassium channels. Brain 2001;124: 2417-26.
73 Munsat TL. Therapy of myotonia. A double-blind evaluation of diphenylhydantoin, procainamide, and placebo. Neurology 1967; 17:359-67

74 Griggs RC, Resnick J, Engel WK. Intravenous treatment of hypokalemic periodic paralysis. Arch Neurol 1983;40:539-40.

75 Riggs JE, Griggs RC, Moxley RT 3rd, et al. cute effects of acetazolamide in hyperkalemic periodic paralysis. Neurology 1981;31:725-9.

76 Tawil R, McDermott MP, Brown R Jr, et al. Randomized trials of dichlorphenamide in the periodic paralyses. Working Group on Periodic Paralysis. Ann Neurol 2000;47:46-53.

77 Griggs RC, Engel WK, Resnick JS. Acetazolamide treatment of hypokalemic periodic paralysis. Prevention of attacks and improvement of persistent weakness. Ann Intern Med 1970;73:39-48.

78 Eunson LH, Rea R, Zuberi SM, et al. Clinical, genetic, and expression studies of mutations in the potassium channel gene KCNAl reveal new phenotypic variability. Ann Neurol 2000;48:647-56.

\section{ANSWERS}

1. A, T; B, F; C, F; D, F. 2. A, F; B,T; C, T; D, F. 3. A, T; B, T; C, T; D, F. 4. A, F; B, T; C, T; D, F. 5. A, F; B, T; C, F; D, F.

\section{Warwick University Short Course}

5-8 April 2005: Techniques and Applications of Molecular Biology: A Course for Medical Practitioners. A four day residential course for those in the medical profession wishing to improve their understanding of the principles and applications of genetic engineering techniques. Details: Dr Charlotte Moonan, Department of Biological Sciences, University of Warwick, Coventry CV4 7AL, UK. Tel: +44 (0)24 7652 3540; fax: +44 (0)24 7652 3701; email: Charlotte.Moonan@warwick.ac.uk. 